\title{
Cold hardiness in Ostrinia nubilalis (Lepidoptera: Pyralidae): Glycerol content, hexose monophosphate shunt activity, and antioxidative defense system
}

\author{
Bojana STANIC ${ }^{1}$, Aleksandra JOVANOVIC-GALOVIC ${ }^{1}$, Dusko P. BLAGOJEVIC ${ }^{2}$, Gordana GRUBOR-LAJSIC ${ }^{1}$, \\ Roger WORLAND ${ }^{3}$ and MiHAJLo B. SPASIC ${ }^{2}$ \\ ${ }^{1}$ Department of Biology and Ecology, Faculty of Sciences, University of Novi Sad, D. Obradovica 2, 21000 Novi Sad, Serbia and \\ Montenegro; e-mail: gordanagl@ib.ns.ac.yu \\ ${ }^{2}$ Institute for Biological Research "Sinisa Stankovic", Department of Physiology, 29. novembra 142, Beograd, Serbia and \\ Montenegro \\ ${ }^{3}$ British Antarctic Survey, National Environment Research Council, High Cross, Madingley Road, Cambridge, UK
}

Key words. Insects, Ostrinia nubialis, antioxidative defense system, hexose monophosphate shunt, cold hardiness, glycerol

\begin{abstract}
Many insects in temperate regions overwinter in diapause, during which they are cold hardy. In these insects, one of the metabolic adaptations to the unfavorable environmental conditions is the synthesis of cryoprotectants/anhydroprotectants. The aim of this study was to investigate the connection between the antioxidative system and synthesis of cryoprotectants (mainly glycerol) in diapausing larvae of the European corn borer, Ostrinia nubilalis (Lepidoptera: Pyralidae). At two periods during diapause (November and February), in three groups of insects (kept under field conditions; $-12^{\circ} \mathrm{C}$ for two weeks; $8^{\circ} \mathrm{C}$ for two weeks), the activity of key enzymes of the antioxidative system and oxidative part of the hexose monophosphate shunt were measured: superoxide dismutase, catalase, non selenium glutathione peroxidase, glutathione S-transferase, glutathione reductase, glucose 6-phosphate dehydrogenase and 6-phosphogluconate dehydrogenase, as well that of the antioxidative components: total glutathione and ascorbate, and dehydroascorbate reductase. There was a higher activity of antioxidative enzymes at the beginning of the diapause period (November) compared to late diapause (February), while glutathione and ascorbate were higher in February. Similarly, there was a lower activity of the hexose monophosphate shunt enzymes in February. Exposure of larvae to $-12^{\circ} \mathrm{C}$ resulted in an elevation of hexose monophosphate shunt enzyme activity, especially in November. This was accompanied by a significant increase in glycerol content in February. Changes in ascorbate levels and dehydroascorbate reductase activity in both experimental groups $\left(-12^{\circ} \mathrm{C}\right.$ and $\left.8^{\circ} \mathrm{C}\right)$ suggest a connection between the antioxidative system, metabolism during diapause and cold hardiness. Our results support the notion that antioxidative defense in larvae of Ostrinia nubilalis is closely connected with metabolic changes characteristic of diapause, mechanisms of cold hardiness involved in diapause and the maintenance of a stable redox state.
\end{abstract}

\section{INTRODUCTION}

In insects that live in temperate climates cold tolerance and winter diapause are often closely linked in time, and survival mainly depends on physiological and biochemical changes that occur in response to low ambient temperatures. Diapause is not a static but a dynamic process, although insect metabolic rate is generally low (Lefevere \& De Kort, 1989; Jovanovic-Galović et al, 2004). The main function of metabolism during this period of gradually falling temperatures appears to be the biosynthesis of low molecular weight organic solutes that act as cryoprotectants. The early work of Chino (1957) on eggs of Bombyx mori suggested a link between diapause and the synthesis of the cryoprotectants glycerol and sorbitol from glycogen. A close correlation between diapause and the accumulation of cryoprotectants, such as polyhydric alcohols and trehalose, is reported for several insect species (Sømme, 1964, 1965; Asahina, 1966, Wyatt, 1969; Mansingh \& Smallman, 1972; Lee et al., 1987). In some other diapausing species, which undergo winter hardening, accumulation of cryoprotective compounds is not connected directly to diapause (Baust \& Miller, 1970; Wood \& Nordin, 1976; Nordin et al., 1984).
Numerous studies have shown that major alterations occur during winter diapause both in the total metabolic flux and in the relative activities of the different metabolic pathways (Wood \& Nordin, 1976; Storey \& Storey, 1989). The contribution of the hexose monophosphate shunt to glycolysis in diapausing larvae of Eurosta solidaginis increases at low temperatures (Tsumuki et al., 1987). The hexose monophosphate shunt is activated during sorbitol and glycerol synthesis in diapausing eggs of Bombyx mori (Kageyama, 1976) and during coldinduced glycerol synthesis in Protophormia terranovae (Wood \& Nordin, 1980). In cold-hardy insects flux through the hexose monophosphate shunt is critically important for generating the reducing equivalents (NADPH) needed for the synthesis of polyol cryoprotectants. It has been shown that for the synthesis of glycerol from glycogen, $86 \%$ of the total carbon flow must be routed through the shunt to generate the required reducing power (Storey \& Storey, 1988).

Studies on the expression and activity of antioxidative enzymes in insects suggest that the regulation of prooxidant/antioxidant equilibrium affects numerous physiological processes and may impair survival, growth, development, fecundity, fertility and adult life span (Allen, 1991; Ahmad, 1992; Pardini, 1995; Orr \& Sohal, 
1994). Recently, some results have suggested that biochemical mechanisms of cold hardiness and freezing injury may be connected with antioxidative defense (Rojas \& Leopold, 1996; Grubor-Lajsic et al., 1997; Joanisse \& Storey, 1998). That the biosynthesis of polyol cryoprotectants is closely connected with antioxidative enzymes is indicated by the presence of the reducing equivalents (NADPH), which are generated through the hexose monophosphate shunt (Fig. 1).

In this study, the connection between the antioxidative defense system, the oxidative part of the hexose monophosphate shunt and synthesis of cryoprotectants (mainly glycerol) in diapausing larvae of the European corn borer, Ostrinia nubilalis Hubner (Lepidoptera: Pyralidae) was investigated. In O. nubilalis, diapause of the fifth instar larvae and cold acclimation commence in autumn. The larvae overwinter inside stalks of corn, and during this period become freeze tolerant and accumulate glycerol (Asahina, 1966). The aim of this research was to investigate the characteristics of the antioxidative defense system in Ostrinia larvae exposed to low temperatures $\left(14\right.$ days, $\left.-12^{\circ} \mathrm{C}\right)$ and in control larvae $\left(14\right.$ days, $\left.8^{\circ} \mathrm{C}\right)$, and to field conditions, at two different periods during diapause (November and February).

\section{MATERIAL AND METHODS}

\section{Chemicals}

All of the chemicals used in this study were purchased from the Sigma Chemical Company (St. Louis, MO, USA), unless indicated otherwise.

\section{Insects}

Diapausing fifth instar larvae of $O$. nubilalis were collected from maize plants in fields in Vojvodina, Serbia. Larvae were collected in November and February, that is at two different times during the diapause period. Three experimental groups were formed: larvae kept under field condition, inside corn stalks, larvae kept at $8^{\circ} \mathrm{C}$ in humid conditions for two weeks and those kept at $-12^{\circ} \mathrm{C}$ but otherwise similar conditions. Prior to the experiments the exposed to $8^{\circ} \mathrm{C}$ and $-12^{\circ} \mathrm{C}$ were kept inside corn stalks exposed to field conditions.

\section{Preparation of whole body homogenates}

Larvae were carefully brushed to remove contaminating particles, weighed and homogenised in ice-cold buffer $(20 \% \mathrm{w} / \mathrm{v}$ $0.05 \mathrm{M}$ phosphate buffer, $\mathrm{pH} 7.0$, with $0.05 \%$ phenylthiourea) in an ice-chilled glass homogenizer. Prior to centrifugation, aliquots were taken for ascorbic acid and total glutathione content determination, and the remaining homogenates were centrifuged at $15000 \mathrm{~g}$ and $4^{\circ} \mathrm{C}$, for $15 \mathrm{~min}$. The supernatants were the source of the enzymes. GST, CAT, GSH-Px and GR activities were measured immediately after centrifugation.

\section{Enzyme assays}

The activity of superoxide dismutase (SOD) was measured by inhibition of superoxide radical production in a xanthinexanthine oxidase reaction, according to the method described by McCord \& Fridovich (1968). One unit of activity was defined as the amount of enzyme necessary to decrease the rate of cytochrome $\mathrm{c}$ reduction to $50 \%$ of maximum at $25^{\circ} \mathrm{C}$ and $\mathrm{pH} 7.8$.

The activity of catalase (CAT) was determined by the rate of hydrogen peroxide disappearance measured at $240 \mathrm{~nm}$, according to Claiborne (1984). One unit of CAT activity was

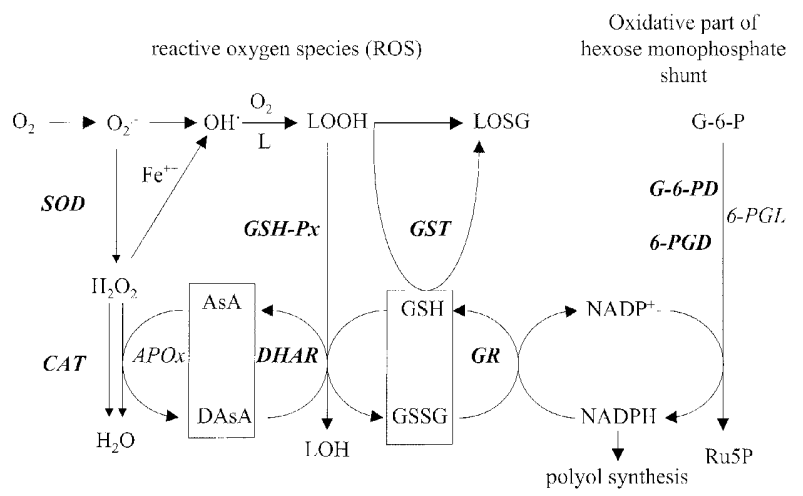

Fig. 1. Connection between the biosynthesis of polyol cryoprotectants and the antioxidative defense system. Antioxidative defense: activities of superoxide dismutase (SOD), catalase (CAT), non selenium glutathione peroxidase (GSH-Px), glutathione-S-transferase (GST), glutathione reductase (GR), as well as the amounts of ascorbate (AsA and DasA) and glutathione (GSH and GSSG); those which are shown bold were measured. Oxygen derived reactive species: superoxide $\left(\mathrm{O}_{2}{ }^{-}\right)$, hydrogen peroxide $\left(\mathrm{H}_{2} \mathrm{O}_{2}\right)$, as well as Fenton reaction $\left(\mathrm{Fe}^{++}\right)$, hydroxyl radicals $(\mathrm{OH})$ and consequently lipid peroxides $(\mathrm{LOOH})$ are presented. Insect antioxidative defense specific components are ascorbate peroxidase (APOx), ascorbate (AsA), dehydroascorbate (DasA) and dehydroascorbate reductase (DHAR) (Blagojevic \& Grubor-Lajsic, 2000). Oxidative part of hexose monophosphate shunt: glucose-6-phosphate dehydrogenase (G-6-PD), 6-phosphogluconate dehydrogenase (6-PGD) and gycerol (polyol); those which are shown in bold were measured. Other: glucose-6-phosphate (G-6-P), 6-phospho-glucoso lactonase (6-PGL), ribuloso-5-phosphate (Ru5P).

defined as the amount of enzyme that decomposes $1 \mathrm{mmol}$ $\mathrm{H}_{2} \mathrm{O}_{2} /$ min at $25^{\circ} \mathrm{C}$ and $\mathrm{pH}$ 7.0.

Glutathione S-transferase (GST) activity, using 1-chloro-2,4-dinitrobenzene as a substrate, was measured as described by Habig et al. (1974). GST activity was monitored at $340 \mathrm{~nm}$ and one unit of GST activity was defined as the amount that utilizes $1 \mathrm{nmol} \mathrm{GSH} / \mathrm{min}$ at $25^{\circ} \mathrm{C}$ and $\mathrm{pH}$ 6.5. GST isozymes can catalyze the decomposition of organic peroxides, and this activity is referred to as non selenium glutathione peroxidase (Prohaska \& Ganther, 1976). The activity of non-selenium glutathione peroxidase (GSH-Px) was determined by the glutathione-dependent reduction of t-butyl hydroperoxide, utilizing a modification of the assay described by Paglia \& Valentine (1967). Specifically, the oxidized glutathione formed by the enzymatic action of GSH-Px is instantly and continuously reduced by an excess of glutathione reductase added to the assay mixture, thereby providing a constant level of reduced glutathione. The concomitant oxidation of NADPH to NADP is monitored spectroscopically at $340 \mathrm{~nm}$. One unit of GSH-Px activity was defined as the amount needed to oxidize $1 \mathrm{nmol}$ $\mathrm{NADPH} / \mathrm{min}$ at $25^{\circ} \mathrm{C}$ and $\mathrm{pH}$ 7.0.

Glutathione reductase (GR) activity was determined using the method of Glatzle et al. (1974). This assay is based on NADPH oxidation concomitant with glutathione reduction. One unit of GR activity was defined as the oxidation of $1 \mathrm{nmol}$ $\mathrm{NADPH} / \mathrm{min}$ at $25^{\circ} \mathrm{C}$ and $\mathrm{pH}$ 7.6.

Dehydroascorbic acid reductase (DHAR) activity was measured as described by Asada (1984). This assay is based on dehydroascorbate reduction to ascorbate by glutathione and is monitored by measuring ascorbate formation at $265 \mathrm{~nm}$. One unit of DHAR activity was defined as the formation of $1 \mathrm{nmol}$ ascorbate $/ \mathrm{min}$ at $25^{\circ} \mathrm{C}$ and $\mathrm{pH} 6.5$. 
The activity of glucose-6-phosphate dehydrogenase (G-6-PD) and 6-phosphogluconate dehydrogenase (6-PGD) was determined using the procedure described by Glock \& McLean (1953). This assay system permits the simultaneous calculation of G-6-PD and 6-PGD activity. These activities were measured indirectly by the rate of reduction of NADP to NADPH at 340 $\mathrm{nm}$. One unit of enzyme activity was defined as the formation of $1 \mathrm{nmol} \mathrm{NADPH} / \mathrm{min}$ at $25^{\circ} \mathrm{C}$ and $\mathrm{pH} 8.0$.

Protein content was determined by the method of Bradford (1976), with bovine serum albumin as a protein standard.

\section{Low molecular weight antioxidants}

Total glutathione (tGSH, reduced and oxidized form) content was measured after homogenate precipitation with $5 \%$ sulfosalicylic acid $(20 \% \mathrm{w} / \mathrm{v})$ and centrifugation at $12000 \mathrm{~g}$ for $5 \mathrm{~min}$. Supernatants were removed and used for the immediate measurement of total glutathione (Griffith, 1980) by first oxidizing reduced glutathione with 5,5'-dithiobis-(2-nitrobenzoic acid) (DTNB) and then reducing the resulting oxidized glutathione with glutathione reductase in the presence of cofactor NADPH. Because this is a cycling reaction, the rate of formation of the chromophoric 2-nitro-5-thiobenzoic acid from DTNB at $412 \mathrm{~nm}$ is proportional to tGSH. Total glutathione concentration in the samples was determined by comparing the rate of change of absorbance with that of glutathione standards of known concentrations $(0.5-4 \mu \mathrm{M})$.

Concentration of ascorbate was determined as previously described by Okamura (1980), using a standard curve prepared with ascorbic acid $(25-400 \mu \mathrm{g} / \mathrm{ml})$. This method enables the simultaneous measurement of the concentration of ascorbic acid and dehydroascorbic acid, i.e. total ascorbate in the sample.

\section{Glycerol content}

Larvae, previously brushed to remove contaminating particles, were weighed and macerated in a glass homogenizer with $1 \mathrm{ml}$ of $70 \%(\mathrm{v} / \mathrm{v})$ ethanol to extract glycerol, and rinsed with $1 \mathrm{ml}$ of $70 \%$ ethanol. Debris was removed from the sample by centrifuging at $12000 \mathrm{~g}$ for $10 \mathrm{~min}$. Before analysis, samples were evaporated to dryness under a stream of nitrogen. Samples for gas chromatography (GC) analysis were derivatized using Sigma-Sil A, according to Sweeley et al. (1963). Aliquots (200 $\mathrm{ml}$ ) of derivatised sample were assayed using a Hewlett Packard gas chromatograph (model 5890, Hewlett Packard Co., California, USA), with an Ultra 2 Hewlett Packard column $(25 \mathrm{~m}$, crosslinked with 5\% Phenyl Methyl silicone) and flame ionization detector.

\section{Statistical analysis}

All results were expressed as mean \pm standard error (SE). Statistical analysis was performed by analysis of variance (ANOVA), and posthoc comparisons were made using Dunc- an's multiple range test. Statistical significance was defined as significant at the level $p<0.05$ (Hinkle et al., 1994).

\section{RESULTS}

To determine the effects of chilling on the antioxidative defense system, possible connection with the oxidative part of the hexose monophosphate shunt and synthesis of cryoprotectant (glycerol), diapausing larvae of Ostrinia nubilalis were exposed to sub-zero temperatures $\left(-12^{\circ} \mathrm{C}\right)$ for two weeks. Ostrinia larvae kept at $8^{\circ} \mathrm{C}$ for the same period of time were the controls.

The activities of antioxidative enzymes in the homogenates of $O$. nubilalis larvae are summarized in Table 1. The activities of the antioxidative enzymes are higher in November than February. After cold exposure, SOD activity was significantly higher only in the November sample. CAT data show that the activity of this enzyme in November increased in Ostrinia larvae kept at $-12^{\circ} \mathrm{C}$ and $8^{\circ} \mathrm{C}$, compared to those kept under field conditions. However, no similar pattern in CAT activity was observed in February. At $-12^{\circ} \mathrm{C}$ an increase in GSH-Px activity was observed in November, but not in February. Cold exposure had no effect on GST activity in either November or January. In November GR activity was significantly higher in control $\left(8^{\circ} \mathrm{C}\right)$ and experimental $\left(-12^{\circ} \mathrm{C}\right)$ Ostrinia larvae, when compared to those exposed to field conditions. On the other hand, compared to those kept under field conditions, GR activity in February was lower in both groups. Upon cold acclimation in November, DHAR activity in Ostrinia larvae was significantly higher only relative to those kept under field conditions. In February, exposure of larvae to $-12^{\circ} \mathrm{C}$ caused an increase in DHAR activity, when compared with control larvae.

The total glutathione content of homogenates of Ostrinia larvae exposed to different temperature conditions was measured and the results are shown in Fig. 2. In November, the level of total GSH in all three experimental groups was very similar. In contrast the Ostrinia larvae showed a statistically significant decrease in the level of total GSH after cold exposure in February compared to those kept under field conditions.

The content of ascorbic and dehydroascorbic acid, i.e. ascorbate in diapausing larvae of $O$. nubilalis after exposure to different temperature regimes is shown in Fig. 3.

TABLE 1. The activities of antioxidant enzymes (units/mg protein) in the homogenates of diapausing 5th instar larvae of Ostrinia nubilalis exposed to different temperature conditions at two periods, November and February. Results are expressed as mean \pm SE. Mean values are based on 6-8 replicates $(n=7-9$ larvae per replicate). * indicates $\mathrm{p}<0.05$ compared to larvae kept under field conditions; $\nabla$ indicates $\mathrm{p}<0.05$ compared to larvae maintained at $8^{\circ} \mathrm{C}$ for 14 days. Units of activity are described in Material and methods. SOD - superoxide dismutase, CAT - catalase, GSH-Px - non-selenium glutathione peroxidase, GST glutathione-S-transferase, GR - glutathione reductase, DHAR - dehydroascorbate reductase.

\begin{tabular}{lccccccc}
\hline & \multicolumn{3}{c}{ November } & & \multicolumn{3}{c}{ February } \\
\cline { 2 - 3 } & Field conditions & 14 days $/ 8^{\circ} \mathrm{C}$ & 14 days $/-12^{\circ} \mathrm{C}$ & & Field conditions & 14 days $/ 8^{\circ} \mathrm{C}$ & 14 days $/-12^{\circ} \mathrm{C}$ \\
\hline SOD & $16.1 \pm 1.3$ & $12.9 \pm 1.1$ & $18.2 \pm 0.9 \nabla$ & & $13.8 \pm 0.7$ & $12.4 \pm 0.5$ & $13.4 \pm 0.2$ \\
CAT & $15.3 \pm 0.7$ & $20.1 \pm 1.2 *$ & $17.2 \pm 0.7 *$ & & $10.4 \pm 0.3$ & $10.4 \pm 0.3$ & $10.4 \pm 0.4$ \\
GSH-Px & $11.2 \pm 0.7$ & $14.3 \pm 1.2 *$ & $17.9 \pm 0.5 * \nabla$ & & $7.5 \pm 0.7$ & $7.1 \pm 0.8$ & $6.2 \pm 0.6$ \\
GST & $221 \pm 14$ & $233 \pm 17$ & $221 \pm 15$ & & $184 \pm 9$ & $174 \pm 11$ & $164 \pm 8$ \\
GR & $4.1 \pm 0.5$ & $11.1 \pm 2.1 *$ & $13.0 \pm 1.2 *$ & & $1.9 \pm 0.2$ & $1.3 \pm 0.1 *$ & $1.3 \pm 0.1 *$ \\
DHAR & $5 \pm 0.5$ & $7.7 \pm 1.5$ & $9.3 \pm 0.6$ & & $2.4 \pm 0.2$ & $1.8 \pm 0.2 *$ & $2.6 \pm 0.2 \nabla$ \\
\hline
\end{tabular}




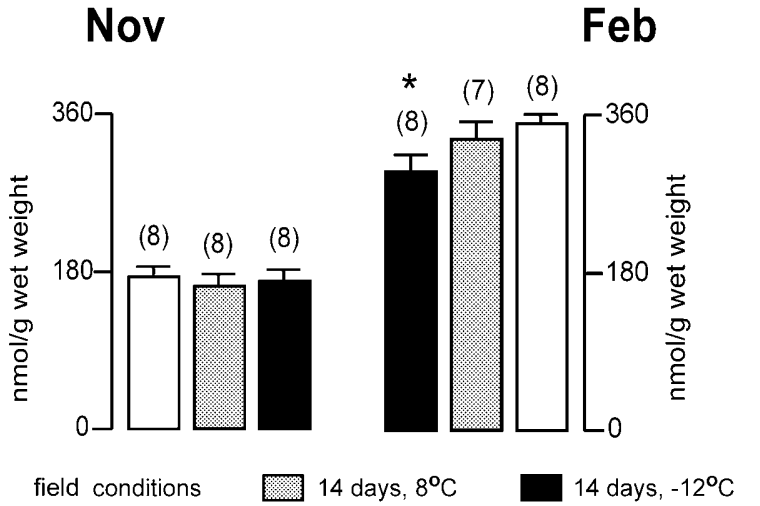

Fig. 2. The total glutathione (GSH and GSSG) content of homogenates of diapausing 5th instar larvae of Ostrinia nubilalis exposed to different temperature conditions in November and February. Results are expressed as mean \pm SE. Numbers in parentheses indicate the number of replicates $(n=7-9$ larvae per replicate). ${ }^{*}$ indicates $\mathrm{p}<0.05$ compared to larvae kept under field conditions.

In both November and February the ascorbate content was higher in controls $\left(8^{\circ} \mathrm{C}\right)$ compared to larvae kept under field conditions. However, the ascorbate content was significantly lower in the experimental group of Ostrinia larvae $\left(-12^{\circ} \mathrm{C}\right)$ than in the controls.

The activities of enzymes of the hexose monophosphate shunt (G-6-PD and 6-PGD) were measured in the homogenates of Ostrinia larvae in order to determine the effect of cold exposure on this metabolic pathway, at two different periods during diapause. The results are presented in Table 2. Upon cold acclimation $\left(-12^{\circ} \mathrm{C}\right)$ in both periods (November and February) G-6-PD activity was significantly elevated compared to the control larvae and those kept under field conditions. On the other hand, 6-PGD activity was increased compared to that of larvae exposed to field conditions, but not compared to the controls.

Glycerol content of the homogenates of diapausing Ostrinia larvae exposed to different temperature conditions is presented in Fig. 4. Exposure of larvae to low temperatures $\left(-12^{\circ} \mathrm{C}\right)$ resulted in a statistically significant elevation of glycerol content in February, but not in November.

\section{DISCUSSION}

Ostrinia nubilalis normaly overwinters in corn stalks as diapausing fifth instar larvae. During this period larvae accumulate glycerol and become freeze tolerant, i.e. they are capable of surviving extracellular ice formation.

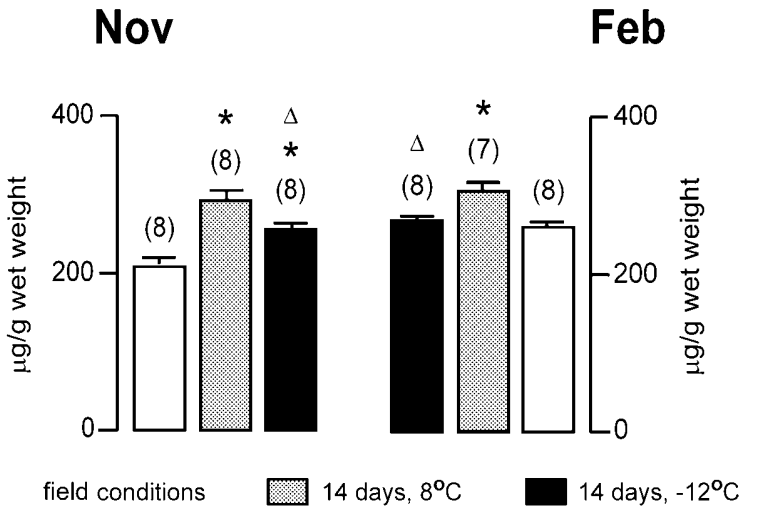

Fig. 3. The ascorbate (AsA and DAsA) content of homogenates of diapausing 5 th instar larvae of Ostrinia nubilalis exposed to different temperature conditions in November and February. Results are expressed as mean \pm SE. Numbers in parentheses indicate the number of replicates $(n=7-9$ larvae per replicate). $*$ indicates $\mathrm{p}<0.05$ compared to larvae kept under field conditions; $\Delta$ indicates $\mathrm{p}<0.05$ compared to larvae maintained at $8^{\circ} \mathrm{C}$ for 14 days.

Although Ostrinia larvae exposed to cold show numerous physiological and biochemical changes, we hypothesize that these metabolic adjustments are connected with changes in the antioxidative defense system. The antioxidative defense system prevents development of oxidative injuries during normal metabolic activity and may be significantly altered by cold stress, due to changes characteristic of diapause and cold hardiness mechanisms.

In this work, antioxidative levels in Ostrinia larvae were measured during diapause (November and February), in order to explore the complexity of the process. Also, the levels of enzymatic and non-enzymatic antioxidants were determined during cold acclimation (14 days, $-12^{\circ} \mathrm{C}$ ) in the laboratory. The significant increase in SOD activity after cold exposure in November (Table 1) emphasizes the importance of this enzyme for the protection of tissues from the oxidative stress associated with the altered metabolic activity during freezing conditions. The dismutation reaction catalyzed by SOD results in the production of hydrogen peroxide, which is further reduced to oxygen and water by catalase action. These two enzymes were assumed to act in tandem and efficiently terminate oxygen radical reactions in insects (Pritsos et al., 1990; Orr \& Sohal, 1994). Although we detected a certain decline in CAT activity (about 15\%) in larvae exposed to sub-zero temperatures in November, it was not significant compared to the control. This may imply a higher activity of another enzymatic system for

TABLE 2. The activities of glucose-6-phosphate dehydrogenase (G-6-PD) and 6-phosphogluconate dehydrogenase (6-PGD) (units/mg protein) in the homogenates of diapausing 5th instar larvae of Ostrinia nubilalis exposed to different temperature conditions at two periods, November and February. Results are expressed as mean \pm SE. Mean values are based on 6-8 replicates ( $n=7-9$ larvae per replicate). $*$ indicates $\mathrm{p}<0.05$ compared to larvae kept under field conditions; $\nabla$ indicates $\mathrm{p}<0.05$ compared to larvae maintained at $8^{\circ} \mathrm{C}$ for 14 days. Units of activity are described in Material and methods.

\begin{tabular}{lccccccc}
\hline & \multicolumn{3}{c}{ November } & & \multicolumn{3}{c}{ February } \\
\cline { 2 - 4 } \cline { 7 - 8 } & Field conditions & 14 days $/ 8^{\circ} \mathrm{C}$ & 14 days $/-12^{\circ} \mathrm{C}$ & & Field conditions & 14 days $/ 8^{\circ} \mathrm{C}$ & 14 days $/-12^{\circ} \mathrm{C}$ \\
\hline G-6-PD & $50.5 \pm 4.5$ & $54.4 \pm 4.5$ & $73.1 \pm 3.1 * \nabla$ & & $41.5 \pm 2$ & $40.7 \pm 1.8$ & $48 \pm 1.8 * \nabla$ \\
6-PGD & $9.5 \pm 1.7$ & $14.2 \pm 1$ & $15.1 \pm 2 *$ & & $8.1 \pm 1$ & $11.1 \pm 1.1 *$ & $12.6 \pm 0.3 *$ \\
\hline
\end{tabular}




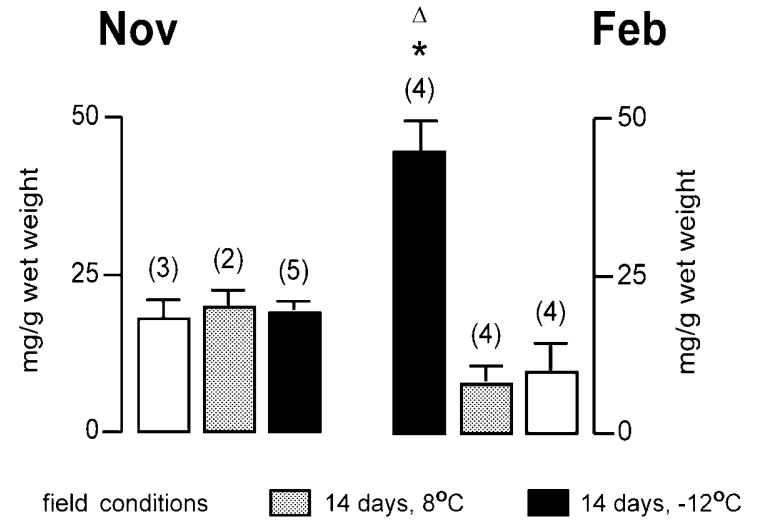

Fig. 4. Glycerol content of homogenates of diapausing 5th instar larvae of Ostrinia nubilalis exposed to different temperature conditions in November and February. Results are expressed as mean \pm SE. Numbers in parentheses indicate the number of replicates $(\mathrm{n}=7-9$ larvae per replicate). $*$ indicates $\mathrm{p}$ $<0.05$ compared to larvae kept under field conditions; $\Delta$ indicates $\mathrm{p}<0.05$ compared to larvae maintained at $8^{\circ} \mathrm{C}$ for 14 days.

$\mathrm{H}_{2} \mathrm{O}_{2}$ removal, which could include ascorbate peroxidase (APOX) and dehydroascorbate reductase (DHAR). Ascorbate peroxidase activity has been found in Helicoverpa zea larvae (Mathews et al., 1997) and two lepidopteran insect cell lines (Wang et al., 2001). Ascorbate peroxidase catalyzes the oxidation of ascorbic acid and concurrent $\mathrm{H}_{2} \mathrm{O}_{2}$ reduction. The resulting dehydroascorbic acid is then converted back to ascorbic acid through the action of DHAR (Felton \& Summers, 1995). Our results on DHAR activity are very similar to that previously reported for other species of lepidopteran larvae (Summers \& Felton, 1993). Upon cold acclimation in November, there was an increase in DHAR activity only when compared to the Ostrinia larvae kept under field conditions (Table 1). Although we detected elevated DHAR activity ( $21 \%$ more than control), it was not statistically significantly different from that of the control. It should be noted that the level of DHAR activity in November correlates well with a high level of GR activity in the same period. These two enzymes are functionally connected and are a part of the ascorbate recycling system in insects (Jovanovic-Galovic et al., 2004). On the other hand, DHAR activity in February was markedly lower in all experimental groups of Ostrinia larvae compared to the November sample. This conforms with the detected decline in the activity of all antioxidative enzymes in February. In addition, the significantly elevated DHAR activity in larvae exposed to low temperatures in February emphasizes the importance of ascorbate recycling in this period of diapause. The general consensus of earlier studies is that selenium-dependent glutathione peroxidase is absent in lepidopteran insect larvae (Ahmad \& Pardini, 1988; Ahmad et al., 1989, Weinhold et al., 1990). These larvae show activity against organic hydroperoxides, but not against $\mathrm{H}_{2} \mathrm{O}_{2}$, which is presumed to be due to a GST isoform (non-selenium-dependent enzyme activity). Therefore, we measured non-selenium glutathione peroxi- dase activity (GSH-Px) using t-butyl hydroperoxide as a substrate. It should be noted that Grubor-Lajsic et al. (1997) previously measured GSH-Px activity in the hemolymph and fat body of diapausing larvae of $O$. nubilalis. Since a very small rate of NADPH oxidation was observed during the enzyme assay (the same rate as in the control), these authors concluded that there was no GSH-Px activity in Ostrinia larvae. As our results clearly demonstrate the presence of GSH-Px like activity in total body homogenates of Ostrinia larvae, it is possible that an isoform of GST is active during diapause in tissues other than hemolymph and fat body. Compared to larvae in November, GSH-Px activity in February was lower in all experimental groups (Table 1). In addition, no significant difference between groups was observed in this period of diapause. On the other hand, there was an elevated GSH-Px activity in larvae exposed to cold in November compared to the control larvae. Therefore, adequate antioxidative protection against freezing during diapause is a prerequisite. GST is present in many insects and usually considered to be involved in the metabolism of insecticides, plant allelochemicals and other xenobiotics (Weinhold, 1990; Fournier et al., 1992; Yu, 1996; Kostaropoulos et al., 2001). The relatively high GST activity in homogenates of Ostrinia larvae in diapause (Table 1), suggest that this enzyme has a role in endogenous metabolic processes, not necessarily connected with feeding. Although the values for GR activity are within the range of values found in the total lysates of a variety of lepidopteran larvae (Pritsos et al., 1988a, b; PericMataruga et al., 1997), the enzyme activity after cold acclimation differed in November and February (Table 1). GR activity in November was markedly elevated in the control $\left(8^{\circ} \mathrm{C}\right)$ and experimental $\left(-12^{\circ} \mathrm{C}\right)$ Ostrinia larvae compared to those exposed to field conditions. This parallels the significant increase in GSH-Px activity, i.e. these two enzymes are functionally connected. Reducing equivalents (NADPH), needed for the action of glutathione reductase, are generated through the hexose monophosphate shunt. As a result of increased GR activity, this metabolic pathway is significantly enhanced (see discussion below). On the other hand, the enzyme activity in February was lower in control and experimental larvae. This positively correlates with the decline in the activity of all GSH-dependent enzymes (GSH-Px, GST, DHAR) during this period of diapause.

Glutathione is considered to be the major thiol-disulfide redox buffer of cells and can react passively as an antioxidant, and restitute enzymes by reduction of oxidized sulfhydryl groups. As the direct reaction of GSH is slow, greater amounts might protect against oxidative stress and supply co-factors for enzymatic reactions as well. The fact that the GSH in homogenates of Ostrinia larvae increased during February (Fig. 2) might compensate for the significant decline in the activity of antioxidative enzymes at this period in diapause. It should be noted that cold exposure had no effect on the content of tGSH during diapause, indicating that glutathione is kept at a high level even after extended exposure to low tempera- 
tures. The content of ascorbate in the homogenates of Ostrinia larvae was significantly elevated in February (Fig. 2), suggesting a compensatory mechanism. Since our results clearly demonstrated significant decrease in the activity of antioxidative enzymes in February, we assume that at this period in diapause it might be the nonenzymatic antioxidants, such as ascorbate, glutathione or $\alpha$-tocopherol, which confer the best protection against oxidative damage. However, the level of ascorbate was significantly lower after cold acclimation in both periods of diapause (Fig. 3), suggesting that this molecule has an important role in freezing conditions. Taking into account the enhanced hexose monophosphate shunt activity during cellular cryoprotection (synthesis of glycerol) under freezing conditions, we hypothesize that dehydroascorbate contributes to the overall activity of this metabolic pathway. Since dehydroascorbate at a physiological $\mathrm{pH}$ is unstable, with a half-life of a few minutes, it may be rapidly metabolized through diketogulonate to 5-carbon intermediates, which could enter the pentose phosphate cycle. In addition, the increased DHAR activity observed in Ostrinia larvae exposed to cold in February (Table 1) could reflect an intense reduction of an oxidized form of ascorbate and the important role of this redox active molecule in numerous redox regulated processes within cells (Schafer \& Buettner, 2001). In conclusion, it should be emphasized that the redox active antioxidants glutathione and ascorbic acid have other regulatory and constitutive physiological functions depending on the availability and production of temporary dominant free radical molecules.

In some species low temperature appears to favour the catabolism of sugars via the hexose monophosphate rather than glycolytic pathway, an adjustment that would generate the reducing power (NADPH) for polyol synthesis. Exposure of larvae to low temperatures resulted in the expected elevation in the activity of HMS enzymes, especially pronounced in November (Table 2). This result is in full agreement with the pronounced GR activity in the Ostrinia larvae kept under freezing conditions. Furthermore, the activity of G-6-PD increased significantly in larvae exposed to sub-zero temperatures during diapause. It was previously demonstrated that G-6-PD from coldhardy insects has high substrate affinity, even at low temperatures, which aids the production of NADPH needed to synthesize polyhydric alcohols from sugars (Storey et al., 1991). Holden \& Storey (1994) previously detected the kinetic properties of 6-PGD from freeze-tolerant larvae of Eurosta solidaginis and concluded that 6-PGD was strongly affected by temperature, i.e. the enzyme was almost completely inhibited at temperatures below $5^{\circ} \mathrm{C}$. Apparently, 6-PGD is less important for generating reducing equivalents for polyol synthesis.

Glycerol is the major cryoprotective polyol in diapausing larvae of $O$. nubilalis. In the laboratory, temperatures triggering glycerol synthesis are in the range from 0 to $5^{\circ} \mathrm{C}$ (Storey \& Storey, 1991). Nordin et al. (1984) showed that the ability of fifth instar Ostrinia larvae to accumulate glycerol depends upon chilling. Eggs, second, third and fourth instar larvae do not have this ability. This indicates that a specific developmental programme is required for insects to respond to cold stress. As expected, diapausing fifth instar larvae of $O$. nubilalis accumulated glycerol in substantial amounts upon exposure to winter conditions. However, glycerol content was significantly higher in Ostrinia larvae in November $(17.96 \mu \mathrm{g} / \mathrm{mg})$ than in February $(9.71 \mu \mathrm{g} / \mathrm{mg})$, indicating that glycerol levels decrease during diapause (Fig. 3). This result agrees with the observations of Grubor-Lajsic et al. (1991) that at the beginning of September glycerol accumulates in the hemolymph of Ostrinia larvae and reaches its highest levels in December and January, after which it declines and is no longer present in spring (April). It should be mentioned that Ostrinia larvae were exposed to slightly different temperatures in November and February. Namely, the average ambient temperature in November was $2.13^{\circ} \mathrm{C}$, whereas in February it reached $6.83^{\circ} \mathrm{C}$, which is exceptionally high for this time of year in Vojvodina. Therefore, we assume that the low glycerol content in February was a response to the relatively high ambient temperatures during that period. Exposure of larvae to low temperatures in the laboratory resulted in the expected elevation in glycerol content only in February, but there was no significant difference in November between the control $\left(8^{\circ} \mathrm{C}\right)$ and experimental group $\left(-12^{\circ} \mathrm{C}\right)$. In November, glycerol made up about $2 \%$ of the total body weight of Ostrinia larvae, suggesting that this relatively high glycerol level could provide adequate cryoprotection, even when exposed to sub-zero temperatures. On the other hand, larvae subjected to freezing conditions in February showed an almost fivefold increase in glycerol concentration $(7.81 \mu \mathrm{g} / \mathrm{mg}$ in controls, 44.58 $\mu \mathrm{g} / \mathrm{mg}$ in chilled larvae). Although there were differences between Ostrinia larvae, the observed elevation in February was too high to be attributed to individual fluctuations in glycerol content. Apparently, larvae enhanced glycerol synthesis in order to survive unfavorable conditions, especially since they experienced unusually high temperatures at the end of January and the beginning of February. It is worth mentioning that insects at different stages of diapause may respond differently to low temperature (Pio \& Baust, 1988), which may account for the different response of Ostrinia larvae to freezing temperatures in November and February. Also, the antioxidative status was different at these two periods in diapause, suggesting a connection between cold hardiness mechanisms and the antioxidative defense system.

In conclusion, the changes in the activity of antioxidative enzymes during diapause suggest that diapause is a dynamic process, which can be divided into phases. In February, the activity of all antioxidative enzymes decreased, accompanied by an increase in the concentration of total glutathione and ascorbate. Glycerol content and the activity of key enzymes of the hexose monophosphate shunt support the proposed connection between this metabolic pathway and the antioxidative system. The present results support the notion that the antioxidative defense system in larvae of Ostrinia nubilalis is closely 
connected with metabolic changes characteristic of diapause and cold hardiness.

ACKNOWLEDGEMENTS. This work was funded by the Ministry for Science, Technologies and Development of the Republic of Serbia, grant no. 1766, project entitled: "Steroidogenic and antioxidative enzymes as sensors to environmentally persistent chemical stressors".

\section{REFERENCES}

Aнmad S. 1992: Biochemical defense of prooxidant plant allelochemicals by herbivorous insect. Biochem. Syst. Ecol. 20: 269-296.

Ahmad S. \& Pardini R.S. 1988: Evidence for the presence of glutathione peroxidase activity toward an organic hydroperoxide in larvae of the cabbage looper moth, Trichoplusia ni. Insect Biochem. 18: 861-866.

Ahmad S., Beilstein M.A. \& Pardini R.S. 1989: Glutathione peroxidase activity in insects: A reassessment. Arch. Insect Biochem. Physiol. 12: 31-49.

AlLEN R.G. 1991: Oxygen-reactive species and antioxidant responses during development: The metabolic paradox of cellular differentiation. Proc. Soc. Exp. Biol. Med. 196: $117-129$.

AsADA K. 1984: Chloroplasts: formation of active oxygen and its scavenging. Meth. Enzymol. 105: 422-429.

Asahina E. 1966: Freezing and frost resistance in insects. In Meryman H.T. (ed): Cryobiology. Academic Press, New York, pp. 451-486.

Baust J.G. \& Miller L.K. 1970: Seasonal variations in glycerol content and its influence on cold hardiness in the Alaskan carabid beetle, Pterostichus brevicornis. J. Insect Physiol. 16: 979-990.

Blagojevic D.P. \& Grubor-Lajsic G. 2000: Multifunctionality of antioxidant system in insects. Arch. Biol. Sci. Belgrade 52: 185-194.

BRADFORD M.M. 1976: A rapid and sensitive method for quantification of microgram quantities of protein utilizing the principle of protein-dye binding. Anal. Biochem. 72: 248-254.

CHINo H. 1957: Conversion of glycogen to sorbitol and glycerol in the diapause egg of the Bombyx silkworm. Nature 180: 606-607.

Claiborne A. 1984: Catalase activity. In Greenwald R.A. (ed.): CRC Handbook of Methods for Oxygen Radical Research. CRC Press Inc., Boca Raton, pp. 283-284.

Felton G.W. \& Summers C.B. 1995: Antioxidant systems in insects. Arch. Insect Biochem. Physiol. 29: 187-197.

Fournier D., Bride J.M., Poirie M., Berge J.P. \& Plapp F.W. 1992: Insect glutathione S-transferases: Biochemical characteristics of the major forms from horseflies susceptible and resistant to insecticides. J. Biol. Chem. 267: 1840-1845.

Glatzle D., Vuilleumier J.P., Weber F. \& Decker K. 1974: Glutathione reductase test with whole blood - a convenient procedure for the assessment of riboflavine status in humans. Experientia 30: 565-638.

Glock G.E. \& McLean P. 1953: Further studies on the properties and assay of glucose-6-phosphate dehydrogenase and 6-phosphogluconate dehydrogenase of rat liver. Biochem. J. 55: $400-408$.

GRIFFITH O.W. 1980: Determination of glutathione and glutathione disulfide using glutathione reductase and 2-vinyl piridine. Anal. Biochem. 106: 207-212.

Grubor-Lajsic G., Block W., Palanacki V. \& Glumac S. 1991: Cold hardiness parameters of overwintering diapause larvae of Ostrinia nubilalis in Vojvodina, Yugoslavia. Cryo-Letters 12: $177-182$.

Grubor-Lajsic G., Block W., Telesmanic M., Jovanovic A., Stevanovic D. \& Baca F. 1997: Effect of cold acclimation on the antioxidant defense system of two larval Lepidoptera (Noctuidae). Arch. Insect Biochem. Physiol. 36: 1-10.

HABIG W.H., PABST M.J. \& JАKOBY W.B. 1974: Glutathione S-transferase. J. Biol. Chem. 249: 7130-7139.

Hinkle E.D., Wiersma W. \& Jurs G.S. 1994. Applied Statistics for Behavioral Sciences. 3rd ed. Houghton Mifflin Company, Boston, 712 pp.

Holden C.P. \& Storey K.B. 1994: 6-phosphogluconate dehydrogenase from a freeze tolerant insect: control of the hexose monophosphate shunt and NADPH production during cryoprotectant synthesis. Insect Biochem. Mol. Biol. 24: 167-173.

JoAnisse D.R. \& Storey K.B. 1998: Oxidative stress and antioxidants in stress and recovery of cold-hardy insects. Insect Biochem. Mol. Biol. 28: 23-30.

Jovanovic-Galovic A., Blagojevic D., Grubor-Lajsic G., WorLAND R. \& SPASIC M.B. 2004: Role of antioxidant defense during different stages of preadult life cycle in European corn borer (Ostrinia nubilalis, Hubn.): diapause and metamorphosis. Arch. Insect Biochem. Physiol. 55: 79-89.

Kageyama T. 1976: Pathways of carbohydrate metabolism in the eggs of the silkworm, Bombyx mori. Insect Biochem. 6: 507-511.

Kostaropoulos I., Papadopoulos A.I., Metaxakis A., Boukouvala E. \& Papadopoulou-Mourkidou E. 2001: Glutathione S-transferase in the defence against pyrethroids in insects. Insect Biochem. Mol. Biol. 31: 313-319.

Lee R.E. Jr, Chen C.P., Meacham M.H. \& Denlinger D.L. 1987: Ontogenetic patterns of cold-hardiness and glycerol production in Sarcophaga crassipalpis. J. Insect Physiol. 33: 587-592.

Lefevere K.S. \& De Kort C.A.D. 1989: Adult diapause in the Colorado potato beetle, Leptinotarsa decemlineata: effects of external factors on maintenance, termination and postdiapause development. Physiol. Entomol. 14: 299-308.

Mansingh A. \& Smallman B.N. 1972: Variation in polyhydric alcohol in relation to diapause and cold-hardiness in the larvae of Isia isabella. J. Insect Physiol. 18: 1565-1571.

Mathews M.C., Summers C.B. \& Felton G.W. 1997: Ascorbate peroxidase: A novel antioxidant enzyme in insects. Arch. Insect Biochem. Physiol. 34: 57-68.

McCord J.M. \& Fridovich I. 1968: The reduction of cytochrome c by milk xanthine oxidase. J. Biol. Chem. 243: 5753-5760.

Nordin J.H., CuI Z. \& YIN C.M. 1984: Cold-induced glycerol accumulation by Ostrinia nubilalis larvae is developmentally regulated. J. Insect Physiol. 30: 563-566.

OKAMURA M. 1980: An improved method for determination of L-ascorbic acid in blood plasma. Clin. Chem. Acta 103: 259-269.

ORR W.C. \& SOHAL R.S. 1994: Extension of life span by overexpression of superoxide dismutase and catalase in Drosophila melanogaster. Science 263: 1128-1130.

Paglia D.E. \& Valentine N.W. 1967: Studies on the quantitative and qualitative characterization of glutathione peroxidase. J. Lab. Clin. Med. 70: 74-77.

PARDINI R.S. 1995: Toxicity of oxygen from naturally occurring redox-active prooxidants. Arch. Insect Biochem. Physiol. 29: 101-118.

Peric-Mataruga V., Blagojevic D., Spasic M.B., Ivanovic J. \& JANKOVIC-HLADNI M. 1997: Effects of host plant on the antioxidative defence in the midgut of Lymantria dispar L. cater- 
pillars of different population origins. J. Insect Physiol. 43: 101-106.

Pio C.J. \& Baust J.G. 1988: Effects of temperature cycling on cryoprotectant profiles in the goldenrod gall fly, Eurosta solidaginis (Fitch). J. Insect Physiol. 34: 767-771.

Pritsos C.A., Ahmad S., Bowen S.M., Blomquist G.J. \& Pardini R.S. 1988a: Antioxidant enzyme activities in the southern armyworm, Spodoptera eridania. Comp. Biochem. Physiol. (C) 90: 423-427.

Pritsos C.A., Ahmad S., Bowen S.M., Elliot A.J., BlomQuist G.J. \& PARDINI R.S. 1988b: Antioxidant enzymes of the black swallowtail butterfly, Papilio polyxenes, and their response to the prooxidant allelochemical, quercetin. Arch. Insect Biochem. Physiol. 8: 101-112.

Pritsos C.A., Ahmad S., Elliot A.J. \& Pardini R.S. 1990: Antioxidant enzyme level response to prooxidant allelochemicals in larvae of the southern armyworm moth, Spodoptera eridania. Free Rad. Res. Comms. 9: 127-133.

Prohaska J.R. \& Ganther H.E. 1976: Glutathione peroxidase activity of glutathione-s-transferases purified from rat liver. Biochem. Biophys. Res. Commun. 76: 437-445.

RoJAs R.R. \& LEOPOLD R.A. 1996: Chilling injury in the housefly: Evidence for the role of oxidative stress between pupariation and emergence. Cryobiology 33: 447-458.

SCHAFER F.Q. \& BuettNer G.R. 2001: Redox environment of the cell as viewed through the redox state of the glutathione disulfide/glutathione couple. Free Rad. Biol. Med. 30: 1191-1212

Søмme L. 1964: Effects of glycerol on cold-hardiness in insects. Can. J. Zool. 42: 89-101.

Sømme L. 1965: Further observations on glycerol and coldhardiness in insects. Can. J. Zool. 43: 765-770.

Storey K.B. \& Storey J.M. 1988: Freeze tolerance in animals. Physiol. Rev. 68: 27-84.

Storey K.B. \& Storey J.M. 1989: Freeze tolerance and freeze avoidance in ectotherms. In Wang L.C.H. (ed.): Advances in
Comparative and Environmental Physiology. Springer, Heidelberg, pp. 51-82.

Storey K.B. \& Storey J.M. 1991: Biochemistry of cryoprotectants. In Lee R.E. \& Denlinger D.L. (eds): Insects at Low Temperature. Chapman and Hall, New York, pp. 64-93.

Storey K.B., Keefe D., Kourtz L. \& Storey J.M. 1991: Glucose-6-phosphate dehydrogenase in cold hardy insects: kinetic properties, freezing stabilization, and control of hexose monophosphate shunt activity. Insect Biochem. 21: $157-164$.

Summers C.B. \& Felton G.W. 1993: Antioxidant role of dehydroascorbic acid in insects. Biochim. Biophys. Acta 1156: 235-238.

Sweeley C.C., Bently R., Makita M. \& Wells W.W. 1963: Gas liquid chromatography of trimethylsilyl derivatives of sugars and related substances. J. Am. Chem. Soc. 85: 2497-2506.

Tsumuki H., Rojas R.R., Storey K.B. \& Baust J.G. 1987: The fate of $\left[{ }^{14} \mathrm{C}\right]$ glucose during cold-hardening in Eurosta solidaginis (Fitch). Insect Biochem. 17: 347-352.

Wang Y., Oberley L.W. \& Murhammer D.W. 2001: Antioxidant defense systems of two lepidopteran insect cell lines. Free Radic. Biol. Med. 30: 1254-1262.

Weinhold L.C., Ahmad S. \& Pardini R.S. 1990: Insect glutathione S-transferase: A predictor of allelochemical and oxidative stress. Comp. Biochem. Physiol. (B) 95: 355-363.

Wood F.E. \& Nordin J.H. 1976: Studies on the low temperature induced biogenesis of glycerol by adult Protophormia terraenovae. J. Insect Physiol. 22: 1665-1673.

Wood F.E. \& Nordin J.H. 1980: Activation of the hexose monophosphate shunt during cold-induced glycerol accumulation by Protophormia terranovae. Insect Biochem. 10: 87-93.

WyatT G.R. 1969: The biochemistry of sugars and polysaccharides in insects. J. Insect Physiol. 4: 287-360.

Yu S.J. 1996: Insect glutathione S-transferases. Zool. Stud. 35: 9-19.

Received August 22, 2003; revised April 28, 2004; accepted May 31, 2004 